\title{
ESTIMATION OF SOIL EROSION AND RIVER SEDIMENT YIELD IN A RURAL BASIN OF NORTH ANATOLIA, TURKEY
}

\author{
OĞUZ, I. $.^{*}-$ SUSAM, T. $^{2}-$ KOCYIGIT, R. ${ }^{1}-$ BICAK, H. ${ }^{1}-$ DEMIRKIRAN, O. ${ }^{3}-$ DEMIR, S. ${ }^{1}$ \\ ${ }^{1}$ Department of Soil Science and Plant Nutrition, Gaziosmanpaşa University, Tokat, Turkey \\ ${ }^{2}$ Department of Geomatics, Gaziosmanpaşa University, Tokat, Turkey \\ ${ }^{3}$ Soil, Fertilizer and Water Resources Central Research Institute, Ankara, Turkey \\ *Corresponding author \\ e-mail:irfan.oguz@gop.edu.tr \\ (Received 14 ${ }^{\text {th }}$ Mar 2019; accepted $3^{\text {rd }}$ May 2019)
}

\begin{abstract}
The aim of the study was to evaluate the sediment prediction performance of Revised Universal Equation (RUSLE) and Musgrave Equation at the Ekinli pond catchment, North central part of Turkey. Ekinli pond was built in 1977 for irrigation purposes. The accumulation of sediment in the ponds negatively affects their functions. There are many dams located within the study area whose operations have been adversely affected by excessive reservoir sedimentation. Accurate estimation of sediment deposition is important in the design of a pond. The calculated amount of sediment volume deposited in the Ekinli reservoir was $21600.75 \mathrm{~m}^{3}$ and the average sediment yield was $514.3 \mathrm{~m}^{3} \mathrm{y}^{-1}$ between 1977 and 2018. In the Ekinli basin, the availability of bathymetry measurements between 1981 and 2006, provided the appropriate conditions to validate the results of the predicted sediment yield since the deposited sediment volume could be quantified as $552.3 \mathrm{~m}^{3} \mathrm{y}^{-1}$. The measured and estimated sediment amounts for the Ekinli reservoir have shown an excellent accordance. In the 42-year time period, 6.74\% of the water storage capacity of the pond has been lost. From 1977 to 2000, the entire basin was grassland and $38 \%$ of the basin area has been afforested. The landuse change reduced a little the amount of sediment in the reservoir. The Mann-Kendal and Theil-Sen Slope estimator statistics indicated a decreasing trend of sediment amount.
\end{abstract}

Keywords: RUSLE, Musgrave Equation, sedimentation, pond, modified Fournier Index, trend analysis, Turkey

\section{Introduction}

Generally, arid and semi-arid ecosystems, where limited rainfalls, floods, droughts and high population restrict rainfed crop production. For the solution of the problem, ponds present a significant contribution as a water conservation structure. The benefit of ponds is to keep water during periods of peak flows, thus preventing flood disasters, and then permit gradual release of water during periods of lower flows.

Pond construction involves high costs and environmental risks. In spite of this, they are built by taking into consideration of the benefits. All ponds negatively affect surface and subsurface hydrology, the aquatic environments of rivers, natural life. But those effects are often negated by the stated purpose of pond as being flood control, irrigation, drinking water supply and other functions. The expected life of a pond is essential for the evaluation of its function, viability, and the economic feasibility. The most important threat on the life of a pond is sedimentation. Deposition of sediment reduces reservoir's active water storage volume and hereby shortens its useful life. It has been reported that the reservoir capacity of world are decreasing each year about $0.5-1.0 \%$ (World Bank, 1998; World Commission on Dams Report, 2000). Soil erosion stands as the major factor controlling sedimentation of reservoirs in semi-arid regions (Wang et 
al., 2016); soils are usually shallower with sparse vegetation, low soil structural stability, non-negligible slopes and intense rainstorms (Cheviron et al., 2011; Gourfi et al., 2018). The useful life of reservoirs is limited by the excess sediment accumulation within the pond (Alighalehbabakhani et al., 2017). Several important factors such as climate change, glacial processes, and human induced activities (urbanization, deforestation, and changes in farm practices) in the watersheds can cause in accelerated soil erosion rates (Jordan et al., 2014; Toy et al., 2002).

There are several erosion models to estimate soil erosion in a field or a basin. One of them is USLE/RUSLE model (Wischmeier and Smith, 1978; Renard et al., 1997). The RUSLE, an empiric model, is a revised form of USLE model. The USLE/RUSLE is one of the most widely used soil erosion model worldwide, as well as in Turkey. Since this model is an erosion model, it needs sediment delivery ratio (SDR) to use in sediment calculations (Jobin et al., 2018). The RUSLE/SDR model has been widely used to evaluate soil erosion and sediment yield in numerous locations due to high efficiency and ease of implementation (e.g., Poirier et al., 2016; Gelagay, 2016; Yan et al., 2018; Ebrahimzadeh et al., 2018; Das et al., 2018; Wijesundara et al., 2018).

The RUSLE model is used with a calibrated SDR to obtain a simulated suspended sediment yield, which was compared with the observed values in 42 catchments of Morocco. The long-term observed values of sedimentation in all selected reservoirs in Morocco showed an annual mean sediment yield of 1.51 million $\mathrm{m}^{3}$. A very strong positive relationship was determined between sedimentation in reservoirs and the corresponding drainage areas. The combination of RUSLE and SDR gave a very strong correlation with the observed suspended sediment yield (Gourfi et al., 2018).

The bathymetric measurement technique can be used to measure sediment yield in a reservoir by subtraction of the pre topographic elevations from current topographic elevations of a reservoir. This technique gives a possibility to compare between simulated sediment estimation to real sediment data in a reservoir.

In the Great Lakes watershed, the sediment accumulation rates of twelve reservoirs were evaluated using the Soil and Water Assessment Tool (SWAT). The estimated sediment accumulation rates by SWAT were compared on radionuclide dating of sediment cores and bathymetric survey methods. Based on the sediment accumulation rate, the remaining reservoir capacity for each study site was estimated. Evaluations of the anthropogenic impacts including land use change and pond construction on the sediment yield were assessed in this research. The regression analysis indicated a strong correlation between sediment yield and drainage area (Alighalehbabakhani et al., 2017).

In the present work, potential soil erosion of Ekinli basin and the sediment accumulation rate within the Ekinli reservoir was assessed by Revised Universal Equation (RUSLE) and Musgrave Equation, using the Geographic Information System (GIS)-based approach for reservoir sediment storage and post and pre-construction pond capacity. The objectives of this study are:

- The validation of applied sediment estimation method by comparing the sediment yields measured with the bathymetric surveys and calculated by some equations.

- To estimate the yearly sediment accumulation rate in the reservoir and predict the remaining capacity of the pond.

- To determine the effect of the partly afforestation on sediment yield in Ekinli basin. 
- To investigate the trends of rainfall and sedimentation and estimate the steepness of the slope used the Mann-Kendall for testing trend and Sen's slope estimator to determine trends of variables in Ekinli basin from 1977 to 2018.

\section{Materials and methods}

\section{Study area}

The study is carried out in the Ekinli basin in the North central part of Turkey, The reservoir was built in 1977 and its basin area is 591 ha. The Ekinli basin is located $49 \mathrm{~km}$ away from Tokat city (Fig. 1).

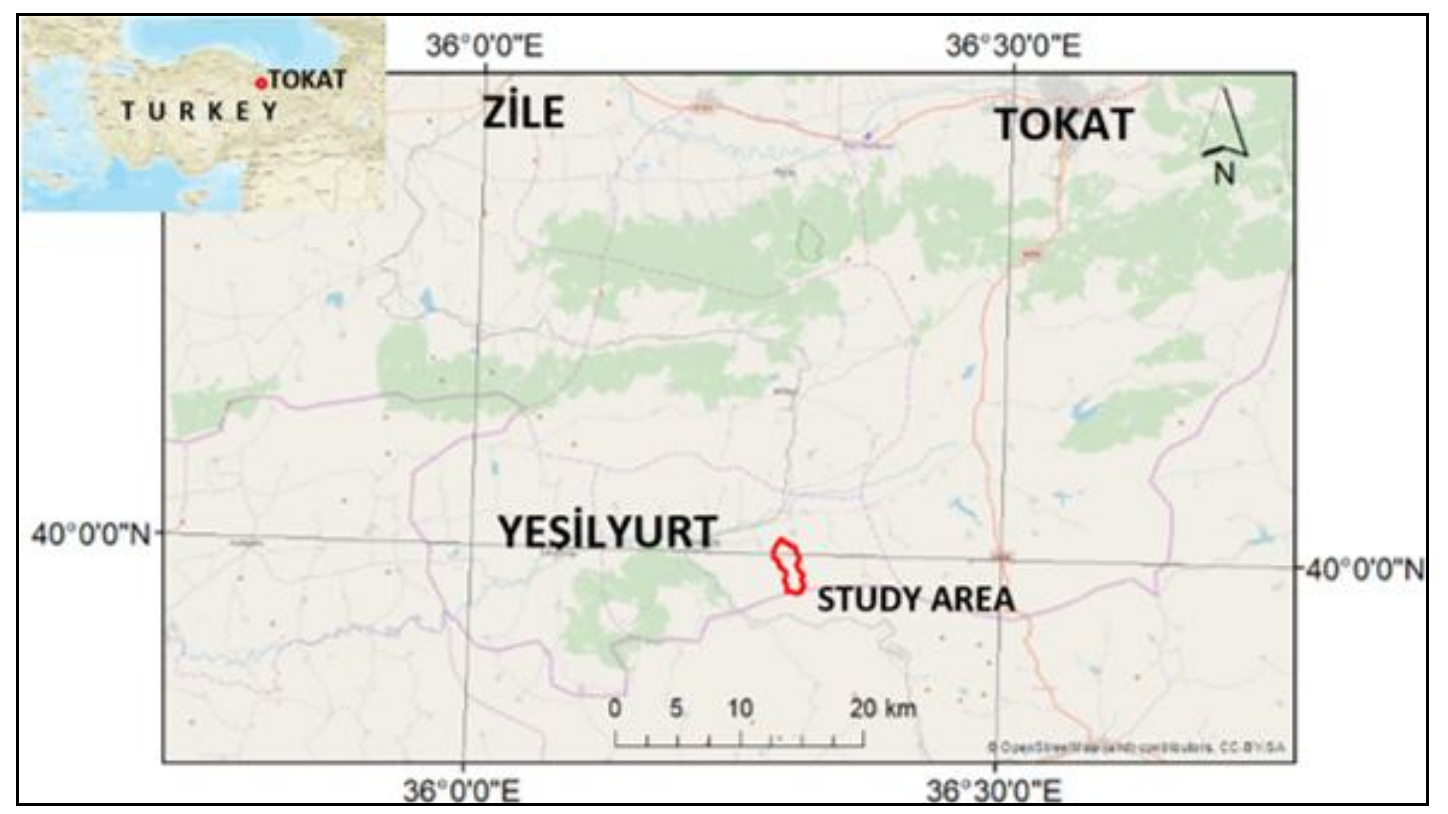

Figure 1. The location of the study area

The Ekinli reservoir at the Cayderesi outlet is a sub-unit of the Yesilirmak basin. Ekinli reservoir basin is located between $36^{\circ} 17^{\prime} 30^{\prime \prime}-36^{\circ} 18^{\prime} 00^{\prime \prime}$ latitudes and $40^{\circ} 00^{\prime} 30^{\prime \prime}-$ $40^{\circ} 01^{\prime} 00^{\prime \prime}$ longitudes. The minimum and maximum elevation is $1118 \mathrm{~m}$ and $1440 \mathrm{~m}$ respectively and the average elevation is $1271 \mathrm{~m}$. The digital elevation model (DEM) of Ekinli Basin is given in Figure 2.

The climate is semi-arid, and the annual precipitation is $419.6 \mathrm{~mm}$. Approximately $49 \%$ of the annual precipitation falls between March and June. The mean annual temperature is $8.1^{\circ} \mathrm{C}$, the highest monthly temperature is in August $\left(19.1^{\circ} \mathrm{C}\right.$ ) and the lowest is in January $\left(-2.1^{\circ} \mathrm{C}\right)$. The mean annual evaporation is $1108 \mathrm{~mm}$. The average snowy days are 22.6 in the basin.

The soils in the basin are calcareous brown forest soils with A and C profiles. Soils are generally vulnerable to degradation with steep slopes and lower vegetation density. The slope varies between 0 and $45 \%$ with an average of $26.15 \%$.

The basin area was completely grassland up to 2000 year. In $2000,38 \%$ of the basin area is converted to forestland. Currently, $38 \%$ of the basin area is forestland and $62 \%$ is grassland (Fig. 3). Some properties of Ekinli basin and reservoir are presented in Table 1 . 


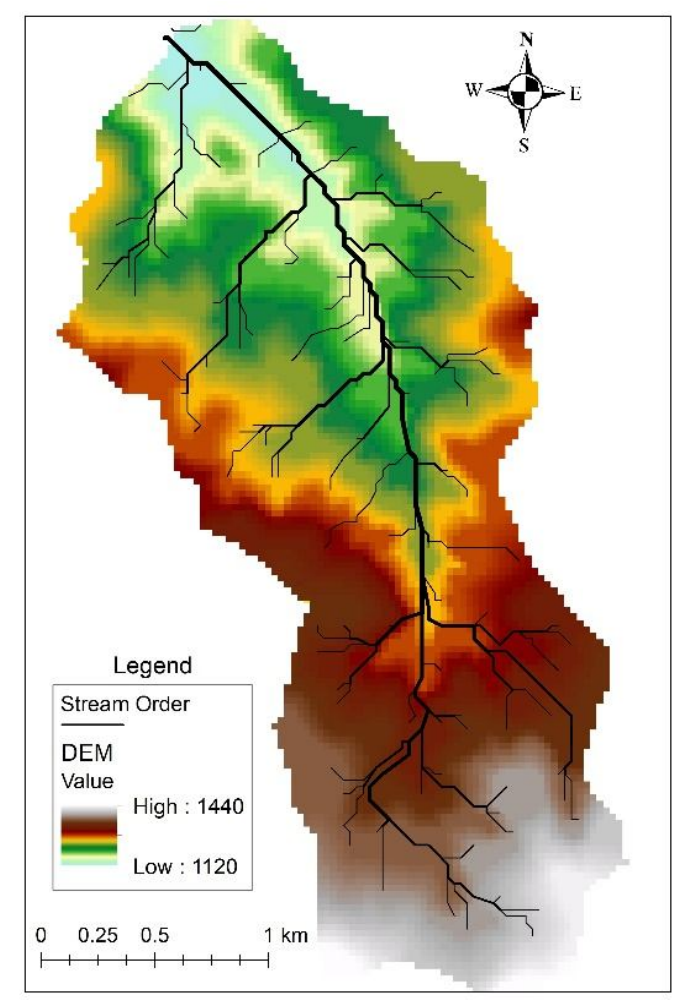

Figure 2. Stream order and digital elevation model of Ekinli Basin

Table 1. Some properties of Ekinli basin and reservoir

\begin{tabular}{|c|c|c|}
\hline Attribute & Symbol & Ekinli pond basin \\
\hline Water district & WD & Northern Turkey \\
\hline Area & $\operatorname{Ar}\left(\mathrm{km}^{2}\right)$ & 5.91 \\
\hline Basin length & $\mathrm{BL}(\mathrm{km})$ & 4.475 \\
\hline Basin width & $\mathrm{BW}(\mathrm{km})$ & 1.29 \\
\hline Basin relief & $\mathrm{r}(\mathrm{m})$ & 312 \\
\hline Minimum elevation & $\operatorname{Hmin}(\mathrm{m})$ & 1118 \\
\hline Mean elevation & Hmean (m) & 1271.03 \\
\hline Median elevation & $\mathrm{Hm}(\mathrm{m})$ & 1220 \\
\hline Maximum elevation & $\operatorname{Hmax}(\mathrm{m})$ & 1440 \\
\hline Mean slope & $\mathrm{J}(\%)$ & 26.15 \\
\hline Circulatory Ratio & $\mathrm{Rc}$ & 0.51 \\
\hline Main stream length & $\mathrm{L}(\mathrm{km})$ & 4.5 \\
\hline Main stream mean slope & Js $(\%)$ & 6.4 \\
\hline Stream length & $\mathrm{Lu}(\mathrm{km})$ & 6.4 \\
\hline Water storage volume & $\mathrm{W}\left(\mathrm{m}^{3}\right)$ & 320370 \\
\hline Active storage volume & As $\left(m^{3}\right)$ & 305635 \\
\hline Dead storage volume & Ds $\left(\mathrm{m}^{3}\right)$ & 14735 \\
\hline Planned Sediment accumulation & Ps $\left(m^{3} 25 y^{-1}\right)$ & 589.4 \\
\hline Crest height & $\mathrm{Cr}(\mathrm{m})$ & 19.5 \\
\hline Crest width & $\mathrm{Cw}(\mathrm{m})$ & 6 \\
\hline Irrigation area & (ha) & 66 \\
\hline
\end{tabular}




\section{Soil and sediment sampling and analyses}

The coordinated soil samples from 150 locations were taken in June 2015 at the basin (Fig. 3). Sediment sampling was done in October when the pond was rather empty. Total 36 sediment samples were taken from crest to river discharge point through a line. Approximately $1000 \mathrm{~cm}^{3}$ of disturbed soil was collected from $0.2 \mathrm{~m}$ depth, then sieved from $2 \mathrm{~mm}$. The disturbed soil samples were used to determine soil organic matter and particle distribution. The undisturbed soil samples were obtained from 0 to $0.20 \mathrm{~m}$ by using a steel ring $(0.05 \times 0.05 \mathrm{~m})$ to determinate saturated hydraulic conductivity and soil bulk density.

Soil organic matter was determined by Walkley-Black methods (Nelson and Sommers, 1982). Soil texture was analyzed using the hydrometer method (Gee and Bauder, 1986). Very fine sand content was measured by sieving (Soil Survey Staff, 1999). Saturated hydraulic conductivity was measured in the undisturbed cores (Black, 1965). Bulk density was determined by the core method (Blake and Hartge, 1986).

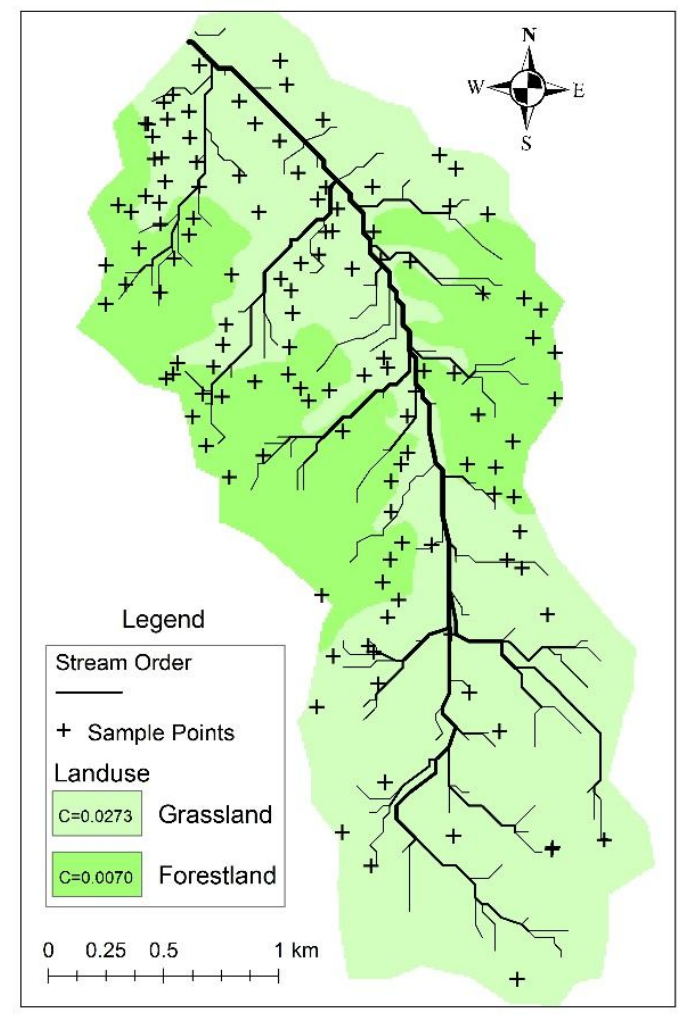

Figure 3. Sample points, landuse and cover management factors map

\section{Bathymetric measurements}

Bathymetric measurements of Ekinli reservoir were done three times in 1981, 1987 and 2006. The depth measurements of Ekinli reservoir were performed at 292 fix gridded points $(10 \times 20 \mathrm{~m})$ in1981 and 1987 years. At these periods, the study was carried out at a limited number of fixed measurement points due to technical difficulties. For this purpose, iron bars were placed along both sides of the pond in order to precisely determine the fixed points. Iron bars were connected to each other by ropes during the measurement times. These ropes enabled the measurements on the same line 
in both measurement periods. The depth measurements were performed with the $10 \mathrm{~m}$ interval for each line. The first two periods of measurement were done by previous researchers using a boat and a plumb. The last measurement was carried out at 11366 points with LAZ 4100 echocaunder in 2006 by our research team. The points were measured by a freely movement of a zodiac boat in the pond.

The water storage volume of the pond was calculated for each measurement period by Surfer Software (Surfer, 1997). According to each bathymetric measurement periods, the reservoir water storage capacities were calculated.

\section{Soil erosion and sediment yield calculation}

The RUSLE erosion model and Musgrave Equation were employed for the calculation of soil loss and sediment yield for the study of basin. Required all calculation were done in geographic information system (GIS) environment within ArcGIS Version 10.1 (ESRI, 2011).

The factors used in the Revised Universal Soil Loss Equation (RUSLE) were used to estimate the average annual soil loss (Renard et al., 1997). According to RUSLE, soil erosion is directly affected by a region's rainfall erosivity, soil erodibility, slope length, slope steepness, land use type and supporting practices. Hereby, mean annual soil loss in per unit of area is estimated from six erosion factors according to Equation 1.

The RUSLE is as follows:

$$
A=R \times K \times L \times S \times C \times P
$$

where $\mathrm{A}$ is computed soil loss (ton $\mathrm{ha}^{-1} \mathrm{y}^{-1}$ ); $\mathrm{R}$ is the rainfall-runoff erosivity factor (MJ $\left.\mathrm{mm} \mathrm{ha} \mathrm{h}^{-1} \mathrm{~h}^{-1} \mathrm{y}^{-1}\right) ; \mathrm{K}$ is a soil erodibility factor $\left(\mathrm{t} \mathrm{h} \mathrm{ha} \mathrm{MJ}^{-1} \mathrm{~mm}^{-1}\right)$; $\mathrm{L}$ is the slope length factor (dimensionless); $\mathrm{S}$ is the slope steepness factor (dimensionless); $\mathrm{C}$ is a cover management factor (dimensionless); and $\mathrm{P}$ is a supporting practices factor (dimensionless).

The rainfall erosivity is determined by the various characteristics of a rainfall event, such as rainfall intensity and duration, the kinetic energy of raindrops, their size (diameter), and velocity (Petan et al., 2010). The unit rainfall energy, as proposed by the RUSLE methodology, is defined by the following equation $(E q .2)$ and is calculated for each time interval as follows (Brown and Foster, 1987).

$$
e_{m}=0,29[1-0,72 \exp (-0,05 i)]
$$

where $\mathrm{e}_{\mathrm{m}}$ is unit rainfall energy $\left(\mathrm{MJ} \mathrm{ha}^{-1} \mathrm{~mm}^{-1}\right)$; $\mathrm{i}$ is rainfall intensity during the time interval $\left(\mathrm{mm} \mathrm{h}^{-1}\right)$.

The calculation of RUSLE R factor required pluviograph records. In Ekinli basin, only daily pluviometer rainfall depth data was available. The Modified Fournier Index (MFI) of Arnoldus (1980) is widely used worldwide to calculate rainfall erosivity which is not available pluviograph data. The MFI is a parameter of rainfall erosivity and makes use of mean monthly and annual rainfall depth data $(E q .3)$. The equation is expressed as:

$$
M F I=\sum_{i=1}^{12} \frac{p i^{2}}{p}
$$


where pi is monthly rainfall depth $(\mathrm{mm}) ; \mathrm{p}$ is annual rainfall depth $(\mathrm{mm})$.

Soil erodibility $(\mathrm{K})$ is the sensitivity of a soil to erosion by runoff and raindrop impact. The higher $\mathrm{K}$ value is the greater the susceptibility of the soil to rill and sheet erosion. Soil erodibility factor was estimated using Equation 4 given by Foster et al. (1991).

$$
100 K=2.1 M^{1.14} 10^{-4}(12-a)+3.25(b-2)+2.5(c-3)
$$

where $\mathrm{K}$ is soil erodibility ( $\mathrm{t} \mathrm{h}$ ha $\mathrm{MJ}^{-1} \mathrm{~mm}^{-1} \mathrm{ha}^{-1}$ ); $\mathrm{M}$ is the particle-size parameter; $\mathrm{a}$ is percent organic matter, $\mathrm{b}$ is soil structure code (very fine granular: 1, fine granular: 2 , medium or coarse granular: 3, and blockish, platy, or massive: 4), which was determined in the field; $\mathrm{c}$ is soil profile permeability class (rapid: 1, moderate-to-rapid: 2, moderate: 3 , slow-to-moderate: 4 , slow: 5 , and very slow: 6 ).

Slope length is defined as the distance from the point of origin of runoff to the point where deposition occurs. The slope length factor (L) was calculated with the help of Equation 5 (Mc Cool et al., 1987).

$$
L=\langle\lambda \mid 22.1\rangle^{m}
$$

where $\mathrm{L}$ is slope length factor (dimensionless), which is field slope length $(\mathrm{m}) ; \mathrm{m}$ is a coefficient that depends on slope steepness, being 0.5 for slopes exceeding $5 \%, 0.4$ for $4 \%$ slopes and 0.3 for slopes less than $3 \%$.

The slope steepness is a site slope, usually expressed as a percentage. The percent slope was determined from DEM with the help of Equation 6.

$$
S=10.8 \sin \theta+0.03 \quad s<9 \% \quad S=16.8 \sin \theta-0.05 \quad s \geq 9 \%
$$

where $\mathrm{S}$ is slope steepness factor (dimensionless) and $\Theta$ is slope angle in degree.

In the RUSLE, the subfactor $\mathrm{C}$ were calculated by Equation 7 . In this method, a factor called soil loss ratio (SLR) for given conditions is calculated by using 5 different subfactors.

$$
S L R=P L U * C C * S C * S R * S M
$$

where PLU is the prior land use subfactor, $\mathrm{CC}$ is the canopy subfactor, $\mathrm{SC}$ is the surface cover subfactor, SR is the surface roughness subfactor, and SM is the soil moisture subfactor.

Once the SLR's have been calculated for each time interval, they are multiplied by their corresponding percentage of annual EI (Wischmeier and Smith 1978). These values are then summed and divided by the total percentage of annual EI value for the entire time period (Eq. 8) (Renard et al., 1997).

$$
C=\left(S L R_{1} * E I_{1}+S L R_{2} * E I_{2}+\cdots \cdots+S L R_{n} * E I_{n} / E I_{t}\right)
$$

where $C$ is average annual or crop value; $S_{L} R_{i}$ is the value for time period $i ; E I_{i}$ is percentage of the annual or crop EI occurring during that time period; $n$ is number of periods used in the summation; and $\mathrm{EI}_{t}$ is sum of the EI percentages for the entire time 
period. The cover management factor ( $\mathrm{C}$ factor) represents a combined effect of interrelated cover and management variables.

Erosion control practices factor $(\mathrm{P})$ is determined to be the ratio between the soil losses expected for a certain soil conservation practice and that of up-and-down slope ploughing (Liu et al., 2001). The support practice factor ( $\mathrm{P}$ factor) represents a combined effect of support practices and management variables. They are also known as structural methods for controlling erosion. In an area, if conservation practices are not followed $P$ value should assign as 1 .

RUSLE is a soil erosion model and is not capable to estimate sediment amount directly. The calculated soil loss amount, according to RUSLE model was multiplied by sediment delivery ratio (SDR) of the basin. Thus, calculated soil loss of the basin area has been converted to sediment amount. Therefore, the SDR of the basin is calculated by Renfro Method (Eq. 9).

Renfro (1975) developed an equation relating SDR with the drainage area. It is based on Maner's (1962) equation and the sediment yields observed in 14 watersheds in the Blackland Prairie Area in Texas. The model shows a good relationship between SDR and the drainage area $\left(\mathrm{R}^{2}=0.92\right)$. The equation is expressed as:

$$
\log (S D R)=1.7935-0.14191 * \log (A)
$$

where A is drainage area $\left(\mathrm{km}^{2}\right)$.

The RUSLE equation is only capable of calculating sheet and rill erosions, and cannot calculate bed load. Therefore, for a more realistic calculation, it is necessary to add stream bed load to the calculations made with these equations. To obtain a more realistic sediment estimation, the amount of sediment calculated by the Musgrave Equation (Sevinç, 1993) was added to the amount of sediment calculated by the RUSLE equation. The Musgrave equation (Eq. 10) is given by:

$$
E=U * D * A * Y
$$

where $\mathrm{E}$ is stream bed load $\left(\mathrm{m}^{3} \mathrm{y}^{-1}\right)$; $\mathrm{U}$ is length of waterway $(\mathrm{m})$; $\mathrm{D}$ is eroded coastal height $(\mathrm{m})$; $\mathrm{A}$ is active erosion rate of riverbank $(\%)$ and $\mathrm{Y}$ is horizontal advance distance $(\mathrm{m})$.

In the meteorological variables, parametric and non-parametric approaches have been used over the years. The most frequently used tests for identifying the variations in meteorological variables have been nonparametric. The most popularized approach among them is Mann-Kendal test (Kendall, 1975; Mann, 1945). The Mann-Kendall nonparametric test was used to test for trend $(E q .11)$. This test is calculated as (Mohtar et al., 2015; Yurekli, 2015):

$$
\mathrm{S}=\sum_{\mathrm{i}=1}^{\mathrm{n}-1} \sum_{\mathrm{j}=\mathrm{i}+1}^{\mathrm{n}} \operatorname{sgn}\left(\mathrm{x}_{\mathrm{j}}-\mathrm{x}_{\mathrm{i}}\right)
$$

where $\mathrm{n}$ is the number of event, $\mathrm{Xj}$ and $\mathrm{Xi}$ are the observed events, and sgn is the sign function.

The variance is given by Equation 12: 


$$
\sigma_{S}^{2}=18^{-1}\left[n(n-1)(2 n+5)-\sum_{i=1}^{m} t_{i}\left(t_{i}-1\right)\left(2 t_{i}+5\right)\right]
$$

where $n$ is the number of events, $m$ is the number of tied events, $t_{i}$ is the number of events that are tied. For sample size greater than 10 the test can be given in Equation 13:

$$
Z_{M K}=\left\{\begin{array}{lll}
\frac{S-1}{\sqrt{\sigma_{S}^{2}}} & \text { if } & S>0 \\
0 & \text { if } & S=0 \\
\frac{S+1}{\sqrt{\sigma_{S}^{2}}} & \text { if } & S<0
\end{array}\right.
$$

For increasing rainfall trends, the values of $\mathrm{Z}_{\mathrm{MK}}$ is positive while for decreasing trends the value of $\mathrm{Z}_{\mathrm{MK}}$ is negative.

Sen's estimator for slope is a nonparametric test for the steepness of the trend. For N pairs of data is given in Equation 14:

$$
\mathrm{Q}_{\mathrm{k}}=\frac{\mathrm{x}_{\mathrm{j}}-\mathrm{x}_{\mathrm{i}}}{\mathrm{j}-\mathrm{i}} \text { for } \mathrm{k}=1, \ldots, \mathrm{N}
$$

where $\mathrm{Xj}$ and $\mathrm{Xk}$ are the values at times $\mathrm{j}$ and $\mathrm{k}(\mathrm{j}>\mathrm{k})$ respectively. The $\mathrm{N}$ values of $\mathrm{Qk}$ are ranked from smallest to largest. According to condition that $\mathrm{N}$ is odd or even, the median concerning with total $\mathrm{N}$ values of is calculated by Equation 15:

$$
\mathrm{Q}_{\text {med }}= \begin{cases}\mathrm{Q}_{[(\mathrm{N}+1) / 2]} & \text { if } \mathrm{N} \text { is odd } \\ 2^{-1}\left\{\mathrm{Q}_{[(\mathrm{N}) / 2]}+\mathrm{Q}_{[(\mathrm{N}+2) / 2]}\right\} & \text { if } \mathrm{N} \text { is even }\end{cases}
$$

The confidence interval for $Q_{\text {med }}$ was obtained to determine the significance of the slope.

\section{Results and discussion}

\section{Bathymetric measurements}

In the Ekinli reservoir, three bathymetric measurements were conducted in 1981, 1987 and 2006. The three-dimensional map of the pond according to last bathimetric measurement in 11366 measurement points is given in Figure 4. We considered $1120 \mathrm{~m}$ sea level for volume computations in all bathimetric measurements. The amount of the sediment volumes stored in the pond was calculated on the basis of $\mathrm{x}, \mathrm{y}$ and $\mathrm{z}$ coordinates. The sediment amounts accumulated in the pond during the bathymetric measurement periods are given in Table 2 . 
Table 2. The change in the water storage volume of the Ekinli pond and the amount of sediment accumulation

\begin{tabular}{c|c|c|c|c|c}
\hline \multirow{2}{*}{ Years } & \multirow{2}{*}{$\begin{array}{c}\text { Water storage } \\
\text { capacity, } \mathbf{~ m}^{\mathbf{3}}\end{array}$} & $\begin{array}{c}\text { The amount of sediment } \\
\text { accumulated in the } \\
\text { pond, } \mathbf{m}^{\mathbf{3}}\end{array}$ & $\begin{array}{c}\text { Annual average sediment } \\
\text { amount }\end{array}$ & \multirow{2}{*}{$\begin{array}{c}\text { Water storage } \\
\text { capacity, \% }\end{array}$} \\
\cline { 4 - 5 } & & & $\mathbf{m}^{\mathbf{3}}$ year $^{-1}$ & mm year $^{-1}$ & \\
\hline 1981 & 54873.6 & 0.0 & - & - & 100.00 \\
1987 & 50626.2 & 4247.7 & 707.95 & 0.12 & 92.26 \\
2006 & 45246.5 & 9627.1 & 534.84 & 0.09 & 82.46 \\
\hline
\end{tabular}

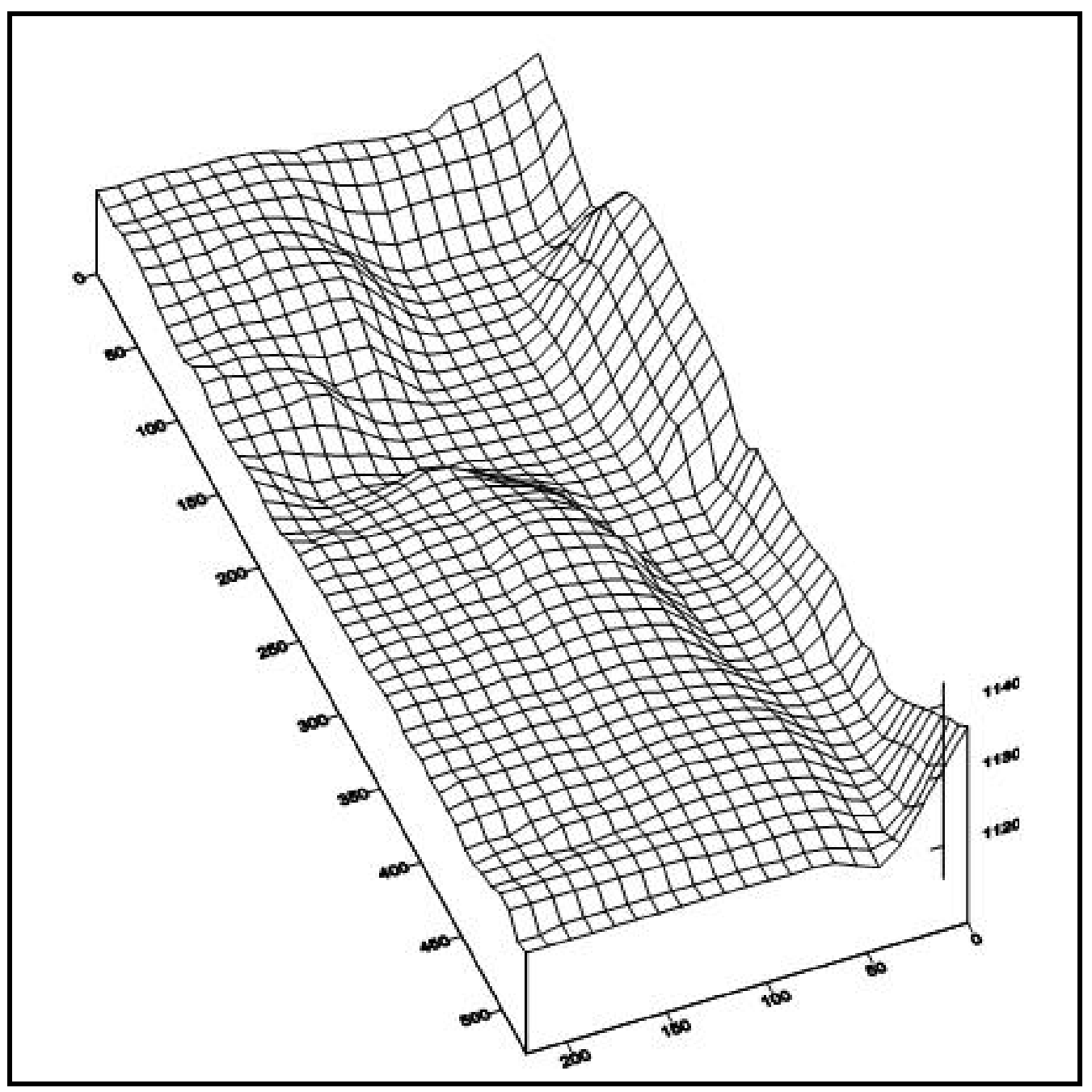

Figure 4. Three-dimensional view of the pond $(\mathrm{m})$

In 1981, the water storage capacity of the pond was calculated as $54873.6 \mathrm{~m}^{3}$ according to $1120 \mathrm{~m}$ sea level by Surfer software. The water storage capacity of the pond decreased gradually due to accumulation of sediment amount during the experimental period. The water storage capacity of the pond decreased by $92.26 \%$ between the years 1981 and 2006. Considering the decrease in water storage capacity, a total of $4247.7 \mathrm{~m}^{3}$ and $9627.1 \mathrm{~m}^{3}$ sediment accumulated in the pond in 1981-1987 and 1987-2006 years respectively. The average sediment accumulation was $707.9 \mathrm{~m}^{3}$ year ${ }^{-1}$ 
in 1981-1987 and 534.8 $\mathrm{m}^{3}$ year $^{-1}$ in 1987-2006 periods, respectively. The decrease in the annual average sediment amount accumulated in the pond between 1987 and 2006 can be attributed to the afforestation of the Ekinli basin. The annual sediment volume to reach the reservoir is estimated as $589.4 \mathrm{~m}^{3} \mathrm{y}^{-1}$ when the pond was planned. The estimation of sediment for pond planning is quite accurate according to the results of the bathymetric measurements.

\section{Sediment properties}

A total 36 surface sediment samples of reservoir base were taken from crest to river discharge point to determine average sediment bulk density and sediment size distribution. The mean bulk density of sediment was measured as $1.48 \mathrm{~g} \mathrm{~cm}^{-3}$. The highest clay and silt contents in the sediments were observed near the crest. The sand content was lower than $30 \%$ at this location. The clay content of sediments was measured over $25 \%$ up to $160 \mathrm{~m}$ from the crest. After this distance the clay content was below 5\%. The silt content of the sediments was greater than $40 \%$, from 0 to $150 \mathrm{~m}$. Maximum sand content was observed at a distance of between 200 and $400 \mathrm{~m}$ from the crest (Fig. 5). Through the reservoir larger suspended particles generally sedimented earlier when reach to the pond compared to the fine particles which usually measured around the crest.

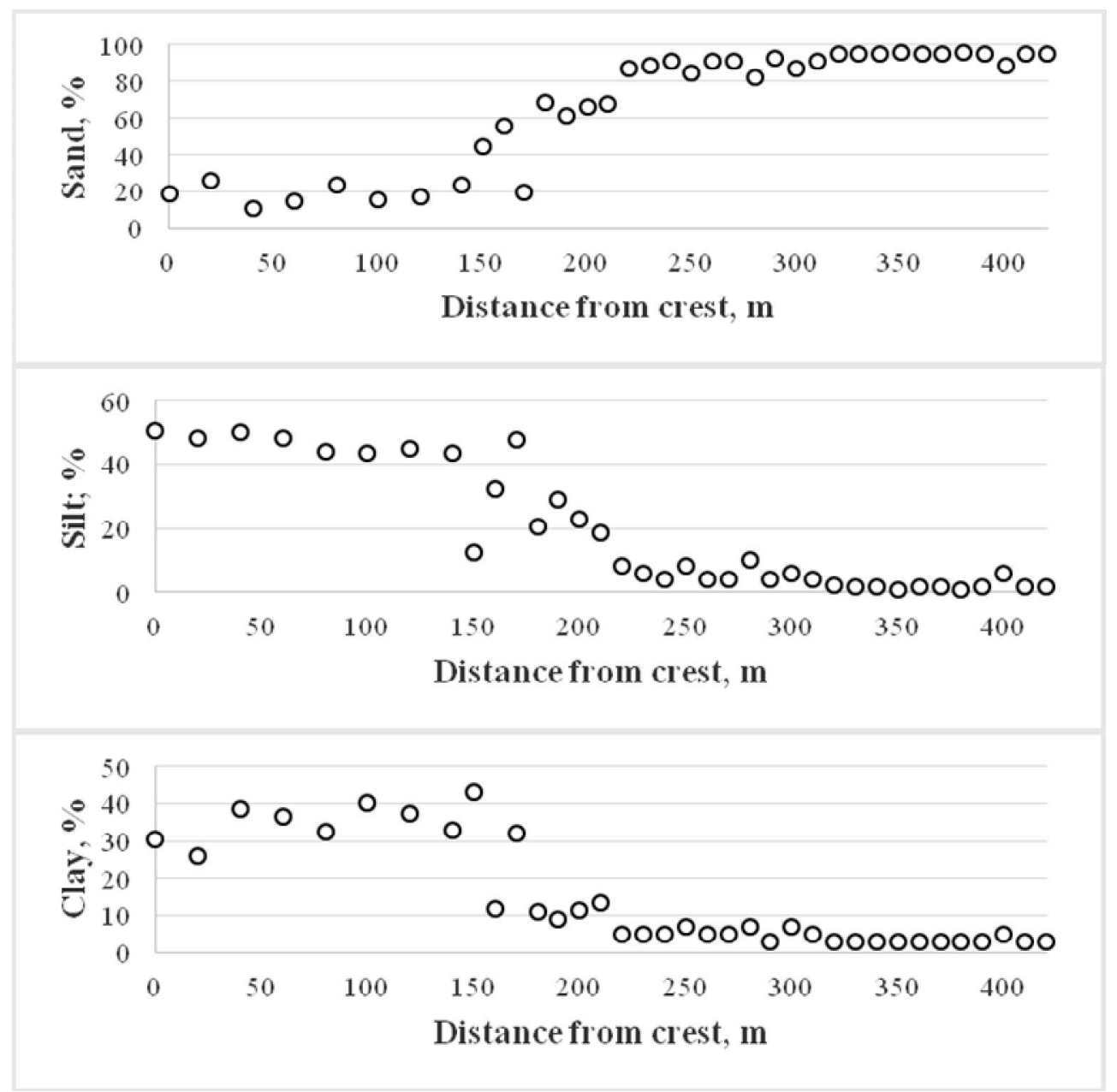

Figure 5. Sediment size distribution according to distance from crest 


\section{Estimation of gross erosion of Ekinli Basin}

Gross erosion includes sheet, rill, gully and channel erosions. The RUSLE estimates sheet and rill erosion only. For this reason, gully and channel erosions were modelled by Musgrave equation in the study $(E q .9)$. The amount of sediment deposited in the pond was estimated by combining RUSLE and the Musgrave methods.

\section{RUSLE erosion model calculations}

As the required input parameters of RUSLE were obtained and prepared in ArcMap for soil loss calculation.

\section{The rainfall erosivity $(R)$ factor}

Several studies showed that rainfall erosivity is one of the most sensitive factor for soil erosion (Ganasri and Ramesh, 2016). In Ekinli basin there were not pluviograph records hence, Modified Fournier Index (MFI) was used for the calculation of R factor. Using the MFI data, Tokat city pluviograph records were used to obtain a more realistic $\mathrm{R}$-factor calculation. Tokat is $49 \mathrm{~km}$ away from the research site and pluviograph records for 18 years are available. The linear regression relationship equation was obtained between $\mathrm{R}$ factor and MFI values of Tokat province by 18 years data (Fig. 6 ). The regression analysis indicated a good correlation between R factor and MFI values. The $\mathrm{R}^{2}$ which represents how close the data are to the regression line is 0.61 . For the erosion studies with high level of uncertainty in the linear model, the $\mathrm{R}^{2}$ of observation and parameter data were found as 0.61 which is adequate for the study.

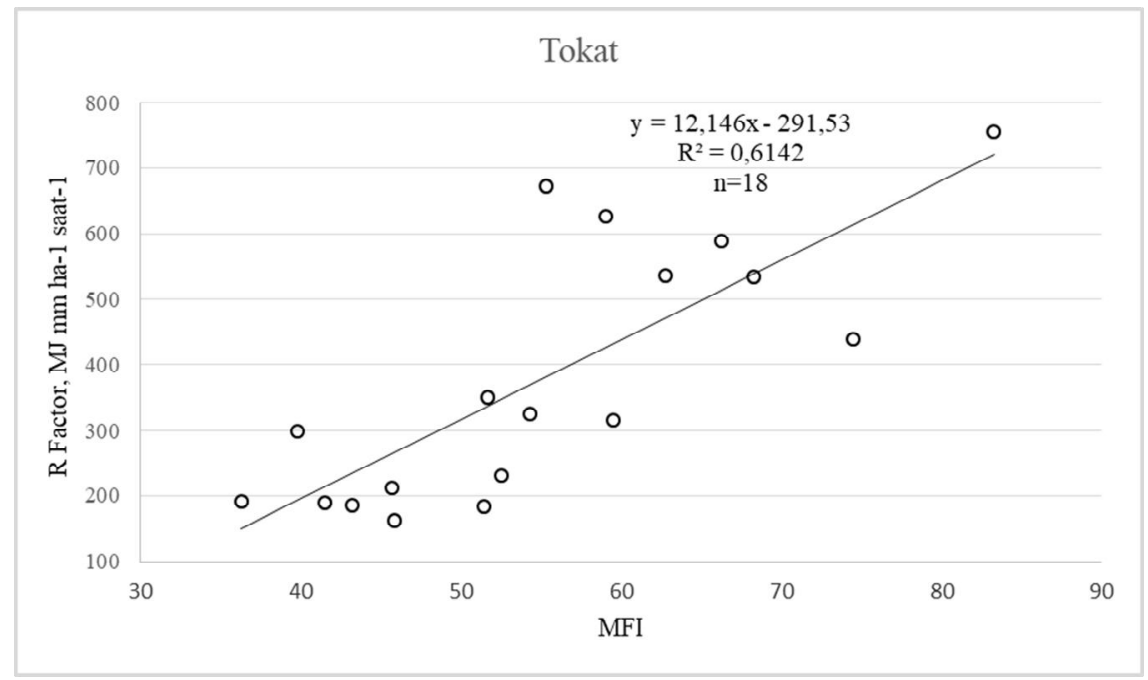

Figure 6. Relationship between $R$ factor and MFI values of Tokat

The linear regression relationship equation between R factor and MFI of Tokat province were applied to Ekinli basin MFI values, which has been calculated from monthly rainfall data. Such regressions using local research areas have been used in literature where no rainfall intensity data are available (Gelagay and Minale, 2016; Zeng et al., 2017). Thus, the annual R-factor values of Ekinli basin were obtained (Table 3). The mean, lowest and highest R Factors values were 415.32, 98.12 and 800.09 MJ mm $\mathrm{ha}^{-1} \mathrm{~h}^{-1} \mathrm{y}^{-1}$ respectively. 
Table 3. The rainfall erosivity factor values of Ekinli basin (1977-2018)

\begin{tabular}{|c|c|c|c|c|c|c|c|}
\hline Year & $\begin{array}{c}\text { R Factor } \\
\text { MJmmha }^{-1} \mathbf{h}^{-1} \mathbf{y r}^{-1} \\
\end{array}$ & Year & $\begin{array}{c}\text { R Factor } \\
\text { MJmmha }^{-1} \mathbf{h}^{-1} \mathbf{y r}^{-1}\end{array}$ & Year & $\begin{array}{c}\text { R Factor } \\
\text { MJmmha }^{-1} \mathbf{h}^{-1} \mathbf{y r}^{-1}\end{array}$ & Year & $\begin{array}{c}\text { R Factor } \\
\text { MJmmha }^{-1} \mathbf{h}^{-1} \mathbf{y r}^{-1}\end{array}$ \\
\hline 1977 & 468.05 & 1988 & 567.51 & 1999 & 328.78 & 2010 & 644.57 \\
\hline 1978 & 241.90 & 1989 & 475.11 & 2000 & 358.03 & 2011 & 331.32 \\
\hline 1979 & 429.57 & 1990 & 502.49 & 2001 & 271.33 & 2012 & 338.25 \\
\hline 1980 & 609.37 & 1991 & 507.60 & 2002 & 317.81 & 2013 & 207.40 \\
\hline 1981 & 392.84 & 1992 & 185.78 & 2003 & 142.07 & 2014 & 416.30 \\
\hline 1982 & 335.12 & 1993 & 563.20 & 2004 & 323.05 & 2015 & 542.25 \\
\hline 1983 & 633.47 & 1994 & 130.47 & 2005 & 224.15 & 2016 & 632.86 \\
\hline 1984 & 932.23 & 1995 & 429.72 & 2006 & 518.08 & 2017 & 235.59 \\
\hline 1985 & 800.09 & 1996 & 501.42 & 2007 & 256.17 & 2018 & 498.29 \\
\hline 1986 & 357.28 & 1997 & 344.84 & 2008 & 98.12 & & \\
\hline 1987 & 390.44 & 1998 & 558.38 & 2009 & 402.06 & Average & 415.32 \\
\hline
\end{tabular}

\section{The K factor}

To estimate the soil erodibility ( $\mathrm{K}$ factor) values indirectly, soil physical features (texture, very fine sand, organic matter, saturated hydraulic conductivity and structural properties) were obtained in topsoil of 150 sampling points in the basin (Wischmeier and Smith, 1978). The soil erodibility characteristics of the Ekinli basin were determined with the help of Equation 4. Coordinated $\mathrm{K}$ factor point values of study area have been converted to $\mathrm{K}$ factor surface map by ArcMap software (Fig. 7).

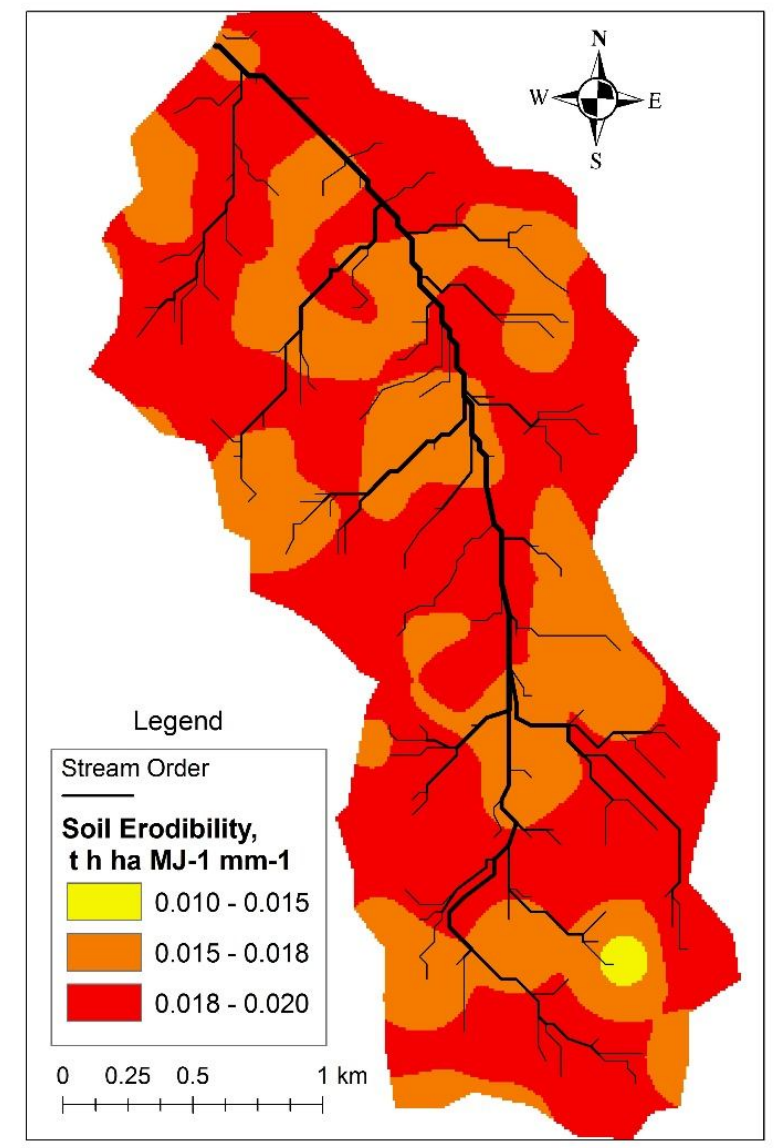

Figure 7. The soil erodibility map 
The spatial distribution of soil erodibility factor map ranged from 0.010 to $0.020 \mathrm{t}$ ha $\mathrm{h} \mathrm{ha} \mathrm{MJ}^{-1} \mathrm{~mm}^{-1}$.

\section{The LS factor}

The slope length factor (L) and the slope steepness factor (S) illustrate the contribution of topography on soil loss. The L factor equals to 1 for $22.1 \mathrm{~m}$ slope length, and the $\mathrm{S}$ factor equals to 1 for $9 \%$ slope. $\mathrm{L}$ and $\mathrm{S}$ factor layers were directly calculated from DEM of the study area by the help of Equations 5 and 6 in ArcMap (Fig. 8). The values of slope length and slope steepness factor (LS) varied from 0 to 22.04 with a mean value of 2.26; the highest values were recorded in areas with high altitudes and slopes, while flat lands had the lowest values.

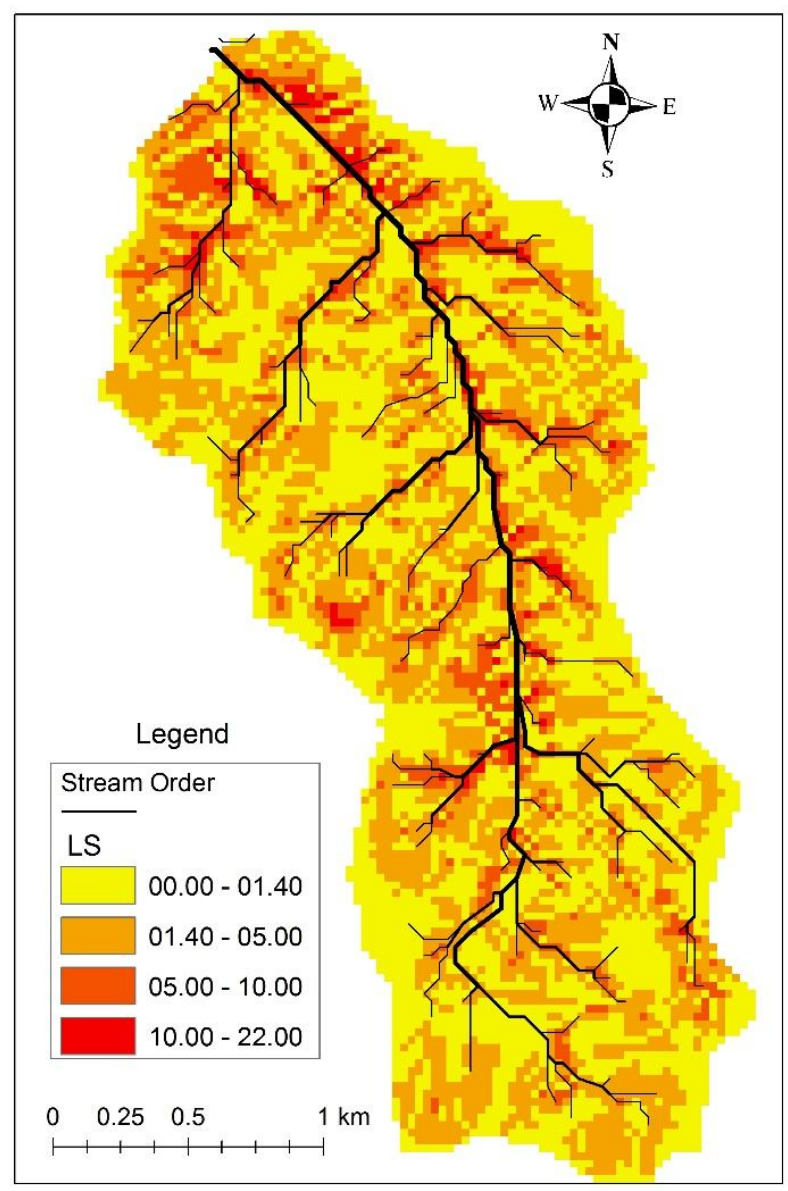

Figure 8. The topographic factor of RUSLE map

\section{The C factor}

In RUSLE, C factor represents the effects of plants, soil cover, soil biomass, and soil disturbing activities on erosion. The $\mathrm{C}$ factor values were determined by $\mathrm{C}$ factor calculation procedure (Renard et al., 1997) based on the field works. Field measurements were done in grassland and forestland separately. Various measurements and vegetation samplings were carried out at both locations in 15 days periods, excluding snow-covered days. A total of 18 field studies were carried out to obtain the 
$\mathrm{C}$ factor values. Some of the data were mass densities of live and dead roots, mass density of incorporated surface residue in the upper depth of soil, fraction of land surface covered by canopy, crop height, surface roughness, percent residue covers and dryweight of crop residue. As a result, SLR value was calculated for different time periods for forest and grassland by the help of Equation 7 (Table 4). Weighted average values was also calculated and annual average $\mathrm{C}$ factor was determined according to Equation 8 for the time frame corresponding to the annual erosion index (EI) value percentage. The annual $\mathrm{C}$ values were calculated as 0.007 and 0.0273 for forestland and grassland of the basin respectively (Fig. 3).

Table 4. Calculated SLR values for forestland and grassland in Ekinli basin

\begin{tabular}{|c|c|c|c|c|c|c|c|c|c|c|c|c|}
\hline Months & \multicolumn{2}{|c|}{ January } & \multicolumn{2}{|c|}{ February } & \multicolumn{2}{|c|}{ March } & \multicolumn{2}{|c|}{ April } & \multicolumn{2}{|c|}{ May } & \multicolumn{2}{|c|}{ June } \\
\hline Forestland & 0.034 & 0.035 & 0.034 & 0.032 & 0.034 & 0.026 & 0.026 & 0.026 & 0.001 & 0.001 & 0.000 & 0.000 \\
\hline Grassland & 0.081 & 0.082 & 0.103 & 0.133 & 0.124 & 0.125 & 0.125 & 0.125 & 0.001 & 0.001 & 0.000 & 0.000 \\
\hline EI. \% & 1.17 & 1.16 & 0.74 & 1.61 & 0.59 & 0.32 & 9.69 & 5.41 & 14.78 & 13.56 & 25.06 & 5.76 \\
\hline Months & \multicolumn{2}{|c|}{ July } & \multicolumn{2}{|c|}{ August } & \multicolumn{2}{|c|}{ September } & \multicolumn{2}{|c|}{ October } & \multicolumn{2}{|c|}{ November } & \multicolumn{2}{|c|}{ December } \\
\hline Forestland & 0.000 & 0.000 & 0.000 & 0.000 & 0.000 & 0.000 & 0.000 & 0.000 & 0.013 & 0.014 & 0.030 & 0.026 \\
\hline Grassland & 0.000 & 0.000 & 0.000 & 0.000 & 0.000 & 0.000 & 0.000 & 0.000 & 0.024 & 0.026 & 0.062 & 0.065 \\
\hline EI. \% & 1.98 & 1.23 & 0.00 & 0.13 & 4.00 & 0.65 & 4.25 & 2.27 & 2.52 & 1.20 & 1.05 & 0.86 \\
\hline
\end{tabular}

\section{The P factor}

The $\mathrm{P}$ factor is computed for individual support practices that are used in combination to reduce erosion. Such practices include terracing, contour tillage, and strip farming. In the case of rare conservation structures in a region, usually P Factor value of 1 is assigned (Tamene et al., 2015). There were no significant conservation measures so we used 1 value for soil loss calculation.

\section{Soil erosion map of basin}

Layers were created in GIS environment for each RUSLE equation factor. Thus, the annual potential sheet and rill erosion were calculated for the basin from 1977 to 2018 . The average soil loss map is presented in Figure 9. The values of soil loss varied from 0 to 4.22 ton $\mathrm{ha}^{-1} \mathrm{y}^{-1}$ with a mean value of 0.36 ; the highest values recorded in areas with high altitudes and slopes, while flat lands had the lowest values.

\section{Sediment delivery ratio of Ekinli basin}

The sediment delivery ratio (SDR) is commonly used in erosion and transport studies to describe the extent of sediment storage within the basin. Ekinli basin with small drainage area and the short distance of fields to the streams created a high SDR potential. Thus, the soil particles of reaching the water channel system are high. In order to calculate the SDR of the basin Renfro Equation (Eq. 9) was used and provided $48.31 \%$ value.

\section{Stream bed load calculation by Musgrave equation}

The waterway length of Ekinli basin is $4500 \mathrm{~m}$. Since there has been active erosion on both sides of the waterway, total coastal length was considered as $9000 \mathrm{~m}$. Eroded 
coastal height is $1.5 \mathrm{~m}$ and active erosion rate is $48.31 \%$ while horizontal advance distance is $0.051 \mathrm{~m}$. According to Equation 10, stream bed load of Ekinli basin was calculated as $332 \mathrm{~m}^{3} \mathrm{y}^{-1}$. This calculated value was added to the amount of sediment computation by RUSLE and the annual total amount of sediment reaching to the pond was determined (Table 5).

The sediment accumulation of reservoir was calculated as $21600.75 \mathrm{~m}^{3}$ for 42 years study period. The minimum $\left(370.03 \mathrm{~m}^{3}\right)$ and the maximum $\left(775.69 \mathrm{~m}^{3}\right)$ sediment amounts were calculated in 2008 and 1984 respectively.

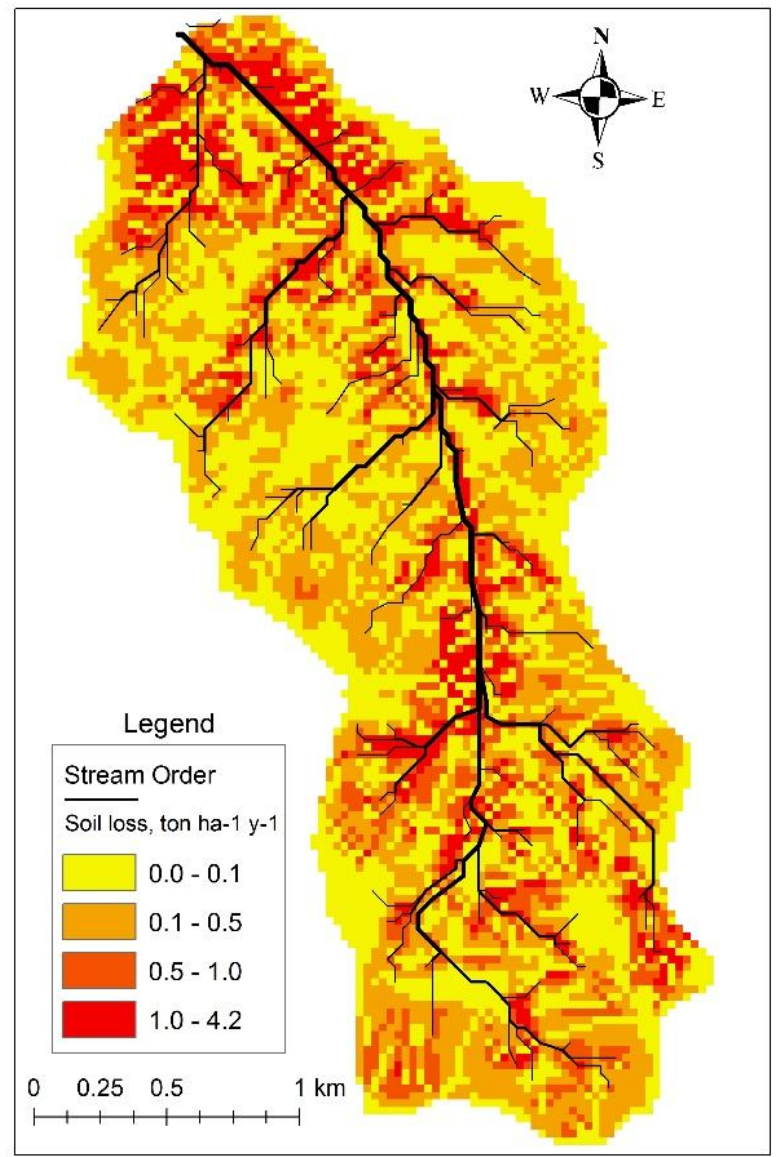

Figure 9. Potential soil loss map of basin according to RUSLE method

\section{Comparison of sediment yield of Ekinli basin measured by bathymetry and computed by RUSLE and Musgrave method}

In our study, the calculated sediment yield was compared with the results of bathymetric measurements. Thus, the accuracy of the calculations was tested. Because the last bathymetric measurement was carried out in 2006, the measurement values performed on this date do not provide sufficient information about the current water storage capacity of the pond. However, it gives valuable information about the validity of the calculations.

The effect of sedimentation on pond is only possible when the basin sediment yield is accurately modeled. Measured and calculated basin sediment yields are compared in Table 6 by comparing two different bathymetric measurement periods. 
Table 5. Total sediment accumulation to the pond

\begin{tabular}{|c|c|c|c|c|}
\hline Year & $\begin{array}{c}\text { Average soil loss (RUSLE) } \\
\text { ton } \mathrm{ha}^{-1} \mathrm{y}^{-1}\end{array}$ & $\begin{array}{c}\text { Sediment (RUSLE) } \\
\mathbf{m}^{3 *}\end{array}$ & $\begin{array}{c}\text { Stream bed load } \\
\text { (Musgrave) } \\
\text { m }^{3}\end{array}$ & $\begin{array}{c}\text { Total sediment } \\
\text { accumulation } \\
\mathbf{m}^{3 * *}\end{array}$ \\
\hline 1977 & 0.53 & 223.96 & 332 & 555.96 \\
\hline 1978 & 0.27 & 114.09 & 332 & 446.09 \\
\hline 1979 & 0.48 & 202.83 & 332 & 534.83 \\
\hline 1980 & 0.69 & 291.56 & 332 & 623.56 \\
\hline 1981 & 0.44 & 185.93 & 332 & 517.93 \\
\hline 1982 & 0.38 & 160.57 & 332 & 492.57 \\
\hline 1983 & 0.87 & 367.63 & 332 & 699.63 \\
\hline 1984 & 1.05 & 443.69 & 332 & 775.69 \\
\hline 1985 & 0.90 & 380.30 & 332 & 712.30 \\
\hline 1986 & 0.40 & 169.02 & 332 & 501.02 \\
\hline 1987 & 0.44 & 185.93 & 332 & 517.93 \\
\hline 1988 & 0.64 & 270.44 & 332 & 602.44 \\
\hline 1989 & 0.54 & 228.18 & 332 & 560.18 \\
\hline 1990 & 0.57 & 240.86 & 332 & 572.86 \\
\hline 1991 & 0.57 & 240.86 & 332 & 572.86 \\
\hline 1992 & 0.21 & 88.74 & 332 & 420.74 \\
\hline 1993 & 0.64 & 270.44 & 332 & 602.44 \\
\hline 1994 & 0.15 & 63.38 & 332 & 395.38 \\
\hline 1995 & 0.49 & 207.05 & 332 & 539.05 \\
\hline 1996 & 0.57 & 240.86 & 332 & 572.86 \\
\hline 1997 & 0.39 & 164.80 & 332 & 496.80 \\
\hline 1998 & 0.63 & 266.21 & 332 & 598.21 \\
\hline 1999 & 0.37 & 156.35 & 332 & 488.35 \\
\hline 2000 & 0.31 & 130.99 & 332 & 462.99 \\
\hline 2001 & 0.24 & 101.41 & 332 & 433.41 \\
\hline 2002 & 0.28 & 118.32 & 332 & 450.32 \\
\hline 2003 & 0.12 & 50.71 & 332 & 382.71 \\
\hline 2004 & 0.28 & 118.32 & 332 & 450.32 \\
\hline 2005 & 0.20 & 84.51 & 332 & 416.51 \\
\hline 2006 & 0.45 & 190.15 & 332 & 522.15 \\
\hline 2007 & 0.22 & 92.96 & 332 & 424.96 \\
\hline 2008 & 0.09 & 38.03 & 332 & 370.03 \\
\hline 2009 & 0.35 & 147.90 & 332 & 479.90 \\
\hline 2010 & 0.56 & 236.63 & 332 & 568.63 \\
\hline 2011 & 0.29 & 122.54 & 332 & 454.54 \\
\hline 2012 & 0.30 & 126.77 & 332 & 458.77 \\
\hline 2013 & 0.18 & 76.06 & 332 & 408.06 \\
\hline 2014 & 0.36 & 152.12 & 332 & 484.12 \\
\hline 2015 & 0.47 & 198.60 & 332 & 530.60 \\
\hline 2016 & 0.55 & 232.41 & 332 & 564.41 \\
\hline 2017 & 0.21 & 88.74 & 332 & 420.74 \\
\hline 2018 & 0.44 & 185.93 & 332 & 517.93 \\
\hline Total & & & & 21600.75 \\
\hline
\end{tabular}

*This value was calculated as: calculated mean soil loss by RUSLE (ton ha- $\left.{ }^{-1} \mathrm{y}^{-1}\right) \times$ basin area $(591 \mathrm{ha}) \times$ bulk density of sediment $\left(1.48 \mathrm{~g} \mathrm{~cm}^{-3}\right) \times$ sediment delivery ratio $(\% 48.31)$

** This value was calculated as: calculated total sediment amount by RUSLE $\left(\mathrm{m}^{3}\right)+$ calculated stream bed load by Musgrave equation $\left(\mathrm{m}^{3}\right)$ 
Table 6. Comparison of measured and calculated sediment yields in Ekinli basin

\begin{tabular}{c|c|c|c|c|c}
\hline \multirow{2}{*}{ Period } & \multicolumn{2}{|c|}{ Measured } & \multicolumn{2}{c|}{ Calculated } & Variation \\
\cline { 2 - 6 } & Total, $\mathbf{m}^{\mathbf{3}}$ & Average, $\mathbf{m}^{\mathbf{3}} \mathbf{y}^{\mathbf{- 1}}$ & Total, $\mathbf{m}^{\mathbf{3}}$ & Average, $\mathbf{m}^{\mathbf{3}} \mathbf{y}^{\mathbf{1}}$ & $\mathbf{m}^{\mathbf{3}}$ \\
\hline $1981-1987$ & 4200 & 600.00 & 4217.06 & 602.44 & +17.06 \\
$1988-2006$ & 9600 & 505.26 & 9540.57 & 502.14 & -59.43 \\
\hline
\end{tabular}

According to the bathymetric measurements, the amounts of sediment deposited in the basin for the periods between 1981-1987 and 1988-2006 were $4200 \mathrm{~m}^{3}$ and $9600 \mathrm{~m}^{3}$, respectively. At the same period, the calculated sediment yield of the Ekinli basin was $4217.06 \mathrm{~m}^{3}$ and $9540.57 \mathrm{~m}^{3}$ respectively.

The first bathymetric measurement period was identified 7 years of sediment accumulation. The average sediment yield was $600 \mathrm{~m}^{3} \mathrm{y}^{-1}$ in this period. Calculated sediment yield was very close to the measured sediment yield during the same period. The predicted sediment yield was only $17.06 \mathrm{~m}^{3}$ higher than the actual measurement results.

The second bathymetric measurement period was identified 19 years of sediment accumulation. The average sediment yield was $505.26 \mathrm{~m}^{3} \mathrm{y}^{-1}$ during this period. At the same period, the calculated sediment yield was also very close to the measured sediment yield. The predicted sediment yield was only $59.43 \mathrm{~m}^{3}$, lower than the actual measurement results.

The measured and estimated sediment amounts for the Ekinli reservoir represented an excellent adaptation. According to this result, it is possible that the estimation of adaptation is also being quite accurate for non-measured years.

\section{The effects of sediment accumulation on the water storage capacity of the pond}

The sluice way height of the pond was planned according to $14735 \mathrm{~m}^{3}$ volume for the 25-year duration, considering the amount of sediment accumulation in the reservoir. For the planning calculations, the dead volume of the pond is expected to be filled in 2001. According to our sediment calculation results, the dead volume of the pond was filled in 2004. The results of the bathymetric measurements confirmed that the dead volume has been filled in the planned period. The bed of reservoir elevated with sediment accumulation over time and the sluice way remained below the current pond floor. However, the special design of the sluice way intake and the whirlpool effect by water movement have ensured seamless water flow from reservoir for irrigation up to date.

In 2017 the open channel irrigation system was canceled and the pipe system was switched to irrigation. Thus, the irrigation area of the pond was expanded.

The cumulative sediment accumulation in the reservoir from 1977 to 2018 is presented in Figure 10. According to our calculations, a total of $21600.75 \mathrm{~m}^{3}$ sediments were deposited in the reservoir for 42 years. According to pond planning calculation, our computation and bathimetric measurements, the mean sediment accumulation were $589.4 \mathrm{~m}^{3}, 514.3 \mathrm{~m}^{3}$ and $552.3 \mathrm{~m}^{3}$ respectively. According to these comparisons, all three computations showed a perfect fit.

Considering the amount of sediment calculated with the help of RUSLE and Musgrave equation, $6.74 \%$ of the total volume of the pond has been filled with sediment. 623 years are required for the pond to be filled completely with sediment. 
RUSLE has been used and accepted by many researchers for erosion prediction because of its high reliability in erosion prediction studies (Ullah et al., 2018). The calculated and measured sediment yields in the basin were very low. The methods used in the study were successful on the prediction of even low sediment yield. Presence of forest and lower mean annual rainfall in the upstream may contribute to comparatively lower erosion rates (Fayas, 2019). In the study area, grassland and forestland had low rainfall erosivity. Therefore, the sediment accumulation calculated in the pond was low.

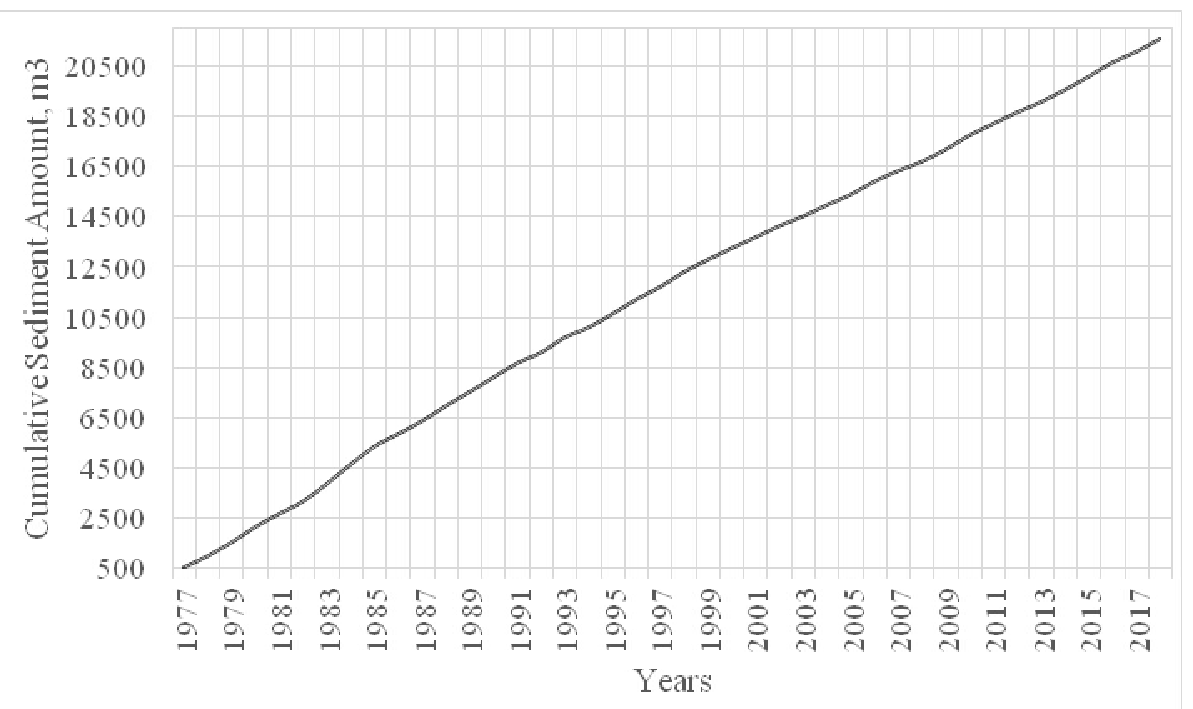

Figure 10. Cumulative sediment accumulation (1977-2018)

\section{The effect of landuse chance on sediment yield}

At the pond planning, the entire Ekinli basin was grassland. So the effects of forestation on sediment yield were not considered when the pond planned. As a result of the afforestation activities carried out in 2010 in the basin, 38\% of the basin area was converted into forestland from grassland. The effect of this landuse change on sedimentation with the help of RUSLE equation was investigated. For this purpose, sediment accumulation was calculated by using RUSLE equation and Musgrave Equation for both situations (whole basin is grassland or $38 \%$ forestland and $62 \%$ grassland) for the years 2000-2018 (Fig. 11).

$\mathrm{C}$ factors values for grassland and forestland were calculated by the help of Equations 7, 8 and the $\mathrm{C}$ value was used to detect of landuse change effect on sediment yield. According to these calculations, forestland was more effective in reducing erosion than grassland. The partial afforestation of the basin caused the sediment yield to drop from $9519 \mathrm{~m}^{3}$ to $8801 \mathrm{~m}^{3}$ between 2000 and 2018. The difference affected only $1.08 \%$ of sediment deposition over a 19-year period. The low difference could be the result of forestland and grassland which have a very close effect on reducing soil losses. Many studies have shown that the changes in land-use or vegetation have a large impact on soil erosion and sedimentation (Diyabalanage et al., 2017; Ganasri and Ramesh, 2016; Zhang et al., 2017; Chen et al., 2019). Conversion of a land from farmland to grassland or forestland is expected to contribute lower sedimentation. In a small basin in Poland, the increase in grassland and forestland at the catchment about $90 \%$ and $10 \%$ 
respectively and a decrease in cultivated land as $82 \%$ reduced soil erosion by $74 \%$ as being calculated using the Revised Universal Soil Loss Equation (Strugała, 2019). The aforestration of Ekinli basin extended the life span from 603 to 623 years.

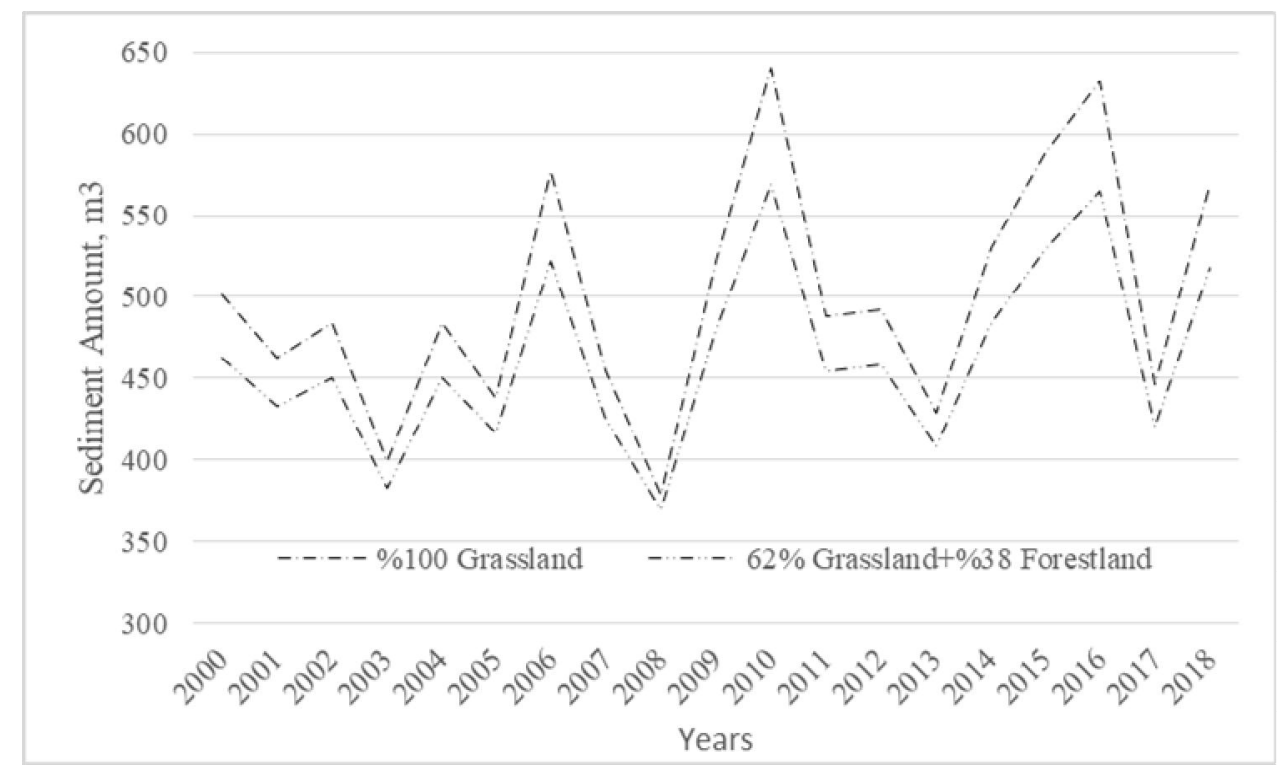

Figure 11. The effect of this landuse change on sedimentation

\section{Trend and slope analyses}

The Mann-Kendall test and Sen's slope estimator were used for rainfall, $\mathrm{R}$ factor and sediment amount of Ekinli basin. The Mann-Kendall statistics for trend and Sen's slope estimator result is given in Table 7. The Mann-Kendall statistics showed significant trend for sediment. The Sen's slope estimator had negative slope. The $\mathrm{H}_{\mathrm{o}}$ hypothesis related to no monotonic trend was rejected for sediment data sets.

There were not a trend for rainfall and $\mathrm{R}$ factor in the basin. The calculated $\mathrm{p}$ value for sediment is smaller than the critical $p$ value from the table of the standard normal distribution.

Although there was no trend for rainfall and rainfall erosivity, the trend for sedimentation was attributed to landuse change after 2000 in the basin.

Table 7. Trend and slope results for Ekinli basin (1977-2018)

\begin{tabular}{c|c|c|c|c}
\hline Parameters & $\mathbf{z}$ & p-value & Sen & CI for Sen \\
\hline Rainfall, $\mathrm{mm}$ & -1.41 & 0.08 & -1.562 & $(-3.848,-0.657)$ \\
R Factor, MJ mm ha ${ }^{-1} \mathrm{~h}^{-1} \mathrm{yr}^{-1}$ & -1.52 & 0.06 & -3.511 & $(-8.193,-1.163)$ \\
Sediment, $\mathrm{m}^{3}$ & -2.77 & 0.00 & -3.002 & $(-5.282,-0.919)$ \\
\hline
\end{tabular}

\section{Conclusion}

The silt accumulation of dams is complex event that affects negatively water storage capacity of pond. The economic life of the ponds are necessary for their sustainability since the most important event effecting the life of the ponds is sedimentation. The agricultural importance of the region has led to the construction of many small ponds. 
The calculations of reasonable sediment amount by the help of RUSLE/SDR and Musgrave equation can be helpful for the new planning of small ponds. This study showed that the GIS systems combined with RUSLE and Musgrave equation is a practical, reliable, inexpensive and relevant method for assessing sediment amount in a basin. The results of the study revealed that the sediment estimation was considerably valid for the basin.

The dead volume of the pond is filled in 2004. Hence, the aquatic life of pond could be under the risk especially in the irrigation seasons. The water storage capacity of the pond decreased by $6.7 \%$ due to sedimentation thus the irrigation potential in the area also decreased. In case the sediment accumulated in the pond would have been spread all over the basin, it would correspond to a soil layer of $3.65 \mathrm{~mm}$ thickness.

The RUSLE equation can be used successfully in sediment calculations. The biggest limitation of this equation is the accurate calculation of the sediment delivery ratio. In addition, calculation of gully and stream erosion by using different methods that the RUSLE equation cannot calculate will provide a more accurate sediment estimation. Even in the lower sedimentation such as grassland and forestland uses the estimation of model was very accurate compared to the results of bathymetric measurements.

According to the results, land use changes from pasture to forest have a poor effect on sediment yield. In order to provide a control on the intensive sedimentation, conversion from cropland to grassland or forestland will be more effective on sedimentation.

\section{REFERENCES}

[1] Alighalehbabakhani, F., Miller, C. J., Baskaran, M., Selegean, J. P., Barkach, J. H., Dahl, T., Abkenar, S. M. S. (2017): Forecasting the remaining reservoir capacity in the Laurentian Great Lakes watershed. - Journal of Hydrology 555: 926-937.

[2] Arnoldus, H. M. J. (1980): An Approximation of Rainfall Factor in the Universal Soil Loss Equation - In: Boodt, M. Gabriels, D. (eds.) Assessment of Erosion. Wiley, Chichester, pp. 127-132.

[3] Black, C. A. (1965): Methods of Soil Analysis Part 2. Chemical and Microbiological Properties. - American Society of Agronom, Inc., Madison, WI, pp. 771-1572.

[4] Blake, G. R., Hartge, K. H. (1986): Bulk Density. - In: Klute, A. (ed.) Methods of Soil Analysis, Part I. Physical and Mineralogical Methods. Agronomy Monograph No. 9. 2nd Ed. ASA, Madison, WI, pp. 363-375.

[5] Brown, L. C., Foster, G. R. (1987): Storm erosivity using idealized intensity distribution. - Transactions of the ASAE 30: 379-386.

[6] Chen, Z., Wang, L., Wei, A., Gao, J., Lu, Y., Zhou, J. (2019): Land-use change from arable lands to orchards reduced soil erosion and increased nutrient loss in a small catchment. - Science of the Total Environment 648: 1097-1104.

[7] Cheviron, B., Delmas, M., Cerdan, O., Mouchel, J. M. (2011): Parameter uncertainty and sensitivity analysis in sediment flux calculation. - Hydrology and Earth System Science 8: 1469-1506.

[8] Das, B., Paul, A., Bordoloi, R., Tripathi, O. P., Pandey, P. K. (2018): Soil erosion risk assessment of hilly terrain through integrated approach of RUSLE and geospatial technology: a case study of Tirap District, Arunachal Pradesh. - Modeling Earth Systems and Environment 4: 373-381.

[9] Diyabalanage, S., Samarakoon, K. K., Adikari, S. B., Hewawasam, T. (2017): Impact of soil and water conservation measures on soil erosion rate and sediment yields in a tropical watershed in the Central Highlands of Sri Lanka. - Applied Geography 79: 103-114. 
[10] Ebrahimzadeh, S., Motagh, M., Mahboub, V., Harijani, F. M. (2018): An improved RUSLE/SDR model for the evaluation of soil erosion. - Environmental Earth Sciences 77: 454.

[11] ESRI (2011): Environmental Systems Research Institute, ArcGIS for Desktop, Version 10.1. - Redlands CD ROM.

[12] Fayas, C. M., Abeysingha, N. S., Nirmanee, K. G. S., Samaratunga, D., Mallawatantri, A. (2019): Soil loss estimation using rusle model to prioritize erosion control in Kelani riverbasin in Sri Lanka. - International Soil and Water Conservation Research 7(2): 130137.

[13] Foster, G. R., Mc Cool, D. K., Renard, K. G., Moldenhauer, W. C. (1991): Conversion of the universal soil loss equation to SI metric units. - Journal of Soil and Water Conservation 36: 355-359.

[14] Ganasri, B. P., Ramesh, H. (2016): Assessment of soil erosion by RUSLE model using remote sensing and GIS-A case study of Nethravathi Basin. - Geoscience Frontiers 7: 953-961.

[15] Gee, G. W., Bauder, J. W. (1986): Particle Size Analysis. - In: Klute, A. (ed.) Methods of Soil Analysis. Part 1. 2nd Ed. Agron. Mongr. 9. ASA, Madison, WI, pp. 383-411.

[16] Gelagay, H. S. (2016): RUSLE and SDR model based sediment yield assessment in a GIS and remote sensing environment: a case study of Koga watershed, upper Blue Nile basin, Ethiopia. - Hydrol Current Res 7(239): 2.

[17] Gelagay, H. S., Minale, A. S. (2016): Soil loss estimation using GIS and Remote sensing techniques: case of Koga watershed, Northwestern Ethiopia. - International Soil and Water Conservation Research 4(2): 126-136.

[18] Gourfi, A., Daoudi, L., Shi, Z. (2018): The assessment of soil erosion risk, sediment yield and their controlling factors on a large scale: Example of Morocco. - Journal of African Earth Sciences 147: 281-299.

[19] Jobin, T., Sabu, J., Thrivikramji, K. P. (2018): Assessment of soil erosion in a monsoondominated mountain river basin in India using RUSLE-SDR and AHP. - Hydrological Sciences Journal 63(4): 542-560.

[20] Jordan, Y. C., Ghulam, A., Hartling, S. (2014): Traits of surface water pollution under climate and land use changes: a remote sensing and hydrological modeling approach. Earth-Science Reviews 128: 181-195.

[21] Kendall, M. G. (1975): Rank Correlation Methods. Fourth Ed. - Charles Griffin, London.

[22] Liu, C., Qi, S., Shi, M. (2001): Process of study on relationship between land use change and soil erosion. - Journal of Soil and Water Conservation 15: 510-513.

[23] Maner, S. B. (1962): Factors influencing sediment delivery ratios in the Blackland Prairie land resource area. - US Dept. of Agriculture, Soil Conservation Service, Fort Worth, TX.

[24] Mann, H. B. (1945): Non-parametric test against trend. - Econometrica 13: 245-259.

[25] Mc Cool, D. K., Foster, G. R., Mutchler, C. K., Meyer, L. D. (1987): Revised slope steepness factor for the universal soil loss equation. - Transactions of the AAE 30(5): 1387-1396.

[26] Mohtar, Z. A., Yahaya, A. S, Ahmad, F. (2015): Rainfall erosivity estimation for Northern and Southern peninsular Malaysia using Fourneir indexes. - Procedia Engineering 125: 179-184.

[27] Nelson, D. W., Sommers, L. E. (1982): Total Carbon, Organic Carbon, and Organic Matter. - In: Page, A. L. (ed.) Methods of Soil Analysis. Part 2. 2nd Ed. Agron. Monogr. 9. ASA and SSSA, Madison, WI, pp. 539-579.

[28] Petan, S., Rusjan, S., Vidmar, A., Mikos, M. (2010): The rainfall kinetic-energy intensity relationship for rainfall erosivity estimation in the Mediterranean part of Slovenia. Journal of Hydrology 391: 314-321. 
[29] Poirier, C., Poitevin, C., Chaumillon, E. (2016): Comparison of estuarine sediment record with modelled rates of sediment supply from a western European catchment since 1500. CR Geosci 348(7): 479-488.

[30] Renard, K. G., Foster, G. A., Weesies, G. A., McCool, D. K. (1997): Predicting soil erosion by water: a guide to conservation planning with RUSLE. - USDA, Agriculture Handbook No. 703, Washington, DC.

[31] Renfro, W. G. (1975): Use of Erosion Equation and Sediment Delivery Ratios for Predicting Sediment Yield. - In: Present and Prospective Technology for Predicting Sediment Yields and Sources. ARS-S-40, US Dept. Agric, Publ., Washington, DC, pp. 33-45.

[32] Sevinc, A. N. (1993): Havza sediment verimi. - KHGM, Ankara Araştirma Enstitusu (in Turkish).

[33] Soil Survey Staff. (1999): Soil Taxonomy: A Basic System of Soil Classification for Making and Interpreting Soil Surveys, - USDA Handbook No. 436. US Government Printing Office, Washington, DC.

[34] Strugała, M. K. (2019): Sediment variability in a small catchment of the Polish Western Carpathians during transition from centrally planned to freemarket economics. Geomorphology 325: 119-129.

[35] Surfer (1997): Surfer for Windows User's Guide. Version 6. - Golden Software Inc., USA.

[36] Tamene, L., Le, Q. (2015): Estimating soil erosion in sub-Saharan Africa based on landscape similarity mapping and using the revised universal soil loss equation (RUSLE). - Nutrient Cycling in Agroecosystems 101: 1-15.

[37] Toy, T. J., Foster, G. R., Renard, K. G. (2002): Soil Erosion: Processes, Prediction, Measurement, and Control. - John Wiley \& Sons, pp. 338.

[38] Ullah, S., Ali, A., Iqbal, M., Javid, M., Imran, M. (2018): Geospatial assessment of soil erosion intensity and sediment yield: a case study of Potohar Region, Pakistan. Environmental Earth Sciences 77: 705.

[39] Wang, X., Zhao, X., Zhang, Z., Yi, L., Zuo, L., Wen, Q., Liu, F., Xu, J., Hu, S., Liu, B. (2016): Assessment of soil erosion change and its relationships with land use/cover change in China from the end of the 1980s to 2010. - Catena 137: 256-268.

[40] Wijesundara, N. C., Abeysingha, N. S., Dissanayake, D. M. S. L. B. (2018): GIS-based soil loss estimation using RUSLE model: a case of Kirindi Oya river basin, Sri Lanka. Modeling Earth Systems and Environment 4(1): 251-262.

[41] Wischmeier, W. H., Smith, D. D. (1978): Predicting rainfall erosion losses. A guide to conservation planning. - USDA Agric. HB No 537, Washington, DC.

[42] World Bank (1998): Sustainability of Dams-Reservoir Sedimentation Management and Safety Implications. - World Bank, Washington, DC.

[43] World Commission on Dams Report (2000): Dams and Development. A New Framework for Decision-Making. - Earthscan Publications Ltd, London, pp. 356.

[44] Yan, R., Zhang, X., Yan, S., Chen, H. (2018): Estimating soil erosion response to land use/cover change in a catchment of the Loess Plateau, China. - International Soil and Water Conservation Research 6: 13-22.

[45] Yurekli, K. (2015): Impact of climate variability on precipitation in the Upper EuphratesTigris Rivers Basin of Southeast Turkey. - Atmospheric Research 154: 25-38.

[46] Zeng, C., Wang, S., Bai, X., Li, Y., Tian, Y., Li, Y., Luo, G. (2017): Soil erosion evolution and spatial correlation analysis in a typical karst geomorphology using RUSLE with GIS. - Solid Earth 8: 721-736.

[47] Zhang, S. H., Fan, W. W., Li, Y. Q., Yi, Y. J. (2017): Influence of changes in land use and landscape patterns on soil erosion in a watershed. - Science of the Total Environment 574: $34-45$. 